\title{
THE EFFECT OF ALTITUDINAL ZONE ON SOIL PROPERTIES, SPECIES COMPOSITION AND FORAGE PRODUCTION IN A SUBALPINE GRASSLAND IN NORTHWEST GREECE
}

\author{
ROUKOS, C. ${ }^{1 *}-$ KOUTSOUKIS, C. $^{2}-$ AKRIDA-DEMERTZI, K. ${ }^{3}-$ KARATASSIOU, M. ${ }^{4}-$ \\ DEMERTZIS, G. P. ${ }^{3}-$ KANDRELIS, S. $^{2}$ \\ ${ }^{1}$ Ministry of Rural Development and Food, Regional Department of Epirus \& Western Greece, \\ Terma Panepistimiou Str, 45110 Ioannina, Greece \\ (phone: +30-26510-40707; fax: +30-26510-41902) \\ ${ }^{2}$ Technological Educational Institute of Epirus, Department of Agricultural Technology, Faculty \\ of Agricultural Technology, Food Technology and Nutrition, Kostakioi - Arta, 47100, Greece \\ (phone: +30-26810-50176; fax: +30-26810-50527) \\ ${ }^{3}$ University of Ioannina, Department of Chemistry, Section of Industrial and Food Chemistry, \\ Food Chemistry Lab., GR 45110 Ioannina, P.O. Box 1186, Greece \\ (phone: +30-26510-08339; fax: +30-26510-07006) \\ ${ }^{4}$ Laboratory of Rangeland Ecology (P.O 286), School of Forestry and Natural Environment, \\ Aristotle University of Thessaloniki, 54124 Thessaloniki Greece \\ (phone: +30-2310-992-302; fax: +30-2310-992-729) \\ *Corresponding author \\ e-mail: roukxris@gmail.com \\ (Received $19^{\text {th }}$ Sep 2016; accepted $30^{\text {th }}$ Dec 2016)
}

\begin{abstract}
The impact of altitudinal gradient on soil properties, species composition and forage production was assessed in the subalpine grassland of "Kostilata" in northwestern Greece. The area is important for endemic species and for its traditional transhumant livestock system. Soil properties, species composition and forage production were determined annually and monthly during three consecutive years (April 2013 - October 2015) from thirty experimental plots located in three altitudinal zones (i.e., lower, middle, and upper). Our results suggested that the altitudinal zone strongly affected soil physical and chemical properties, species composition and forage production. Indeed, altitude a.s.l. was positively correlated with soil sand content and negatively correlated with forage production. It is found that stocking rate exceeded the grazing capacity, which posed a hazard to grassland sustainability; a belief amplified by the high sand content in soil and a terrain with steep slopes, which would increase the risk of further soil erosion at all altitudinal zones.
\end{abstract}

Keywords: altitude, grazing capacity, stocking rate, grassland vegetation, sustainable management

\section{Introduction}

In Greece, subalpine grasslands comprise up to $21 \%$ of the total grassland area. They are characterized by rich flora and high proportion of endemic species (Georghiou and Delipetrou, 2010). In contrast to their small surface, in subalpine grasslands occurs approximately 2000 taxa, about 146 of them are Greek endemics (Papanikolaou et al., 2005). Furthermore, Greece harbors eight grassland habitat types, three of them being priority habitats (Dafis et al., 2001).

This rich heritage plays a key role in viability of livestock production in mountain areas and in sustainability of rural mountain areas resources where livestock products 
characterized from their quality, authenticity and originality (Chatzitheodoridis et al., 2007; McMorran et al., 2015).

Subalpine grasslands are utilized primarily under transhumant livestock system accompanied by the vertical movement of flocks from lowland to highland in order to take advance of the availability of forage production during the summer months (Hadjigeorgiou, 2011).

Indeed, according to the Report of on cohesion policy in mountainous regions of the European Union (European Parliament, 2016), mountain areas produce a large proportion of sheep and goat products (34\% of milk and $25 \%$ of meat), a significant share for bovine products $(9.5 \%$ of milk and $12 \%$ of meat) and less for other animal products such as pork meat.

Ruminant animals cover by grazing their annual feed requirements in a percent ranging from $25 \%$ to $75 \%$ (Zervas, 1998). This figure is up to $50 \%$ of their total production cost (Zioganas et al., 2001). In addition, dairy products can be characterized by special ingredients when livestock feeding with forage from species rich grasslands (Noziere et al., 2006).

Altitude a.s.l. has been recognized as a main factor that influences abiotic environment by altering climatic variables and topography (Holechek et al., 2010). As the main area of subalpine grasslands characterized by steep slopes, it seems that topography, based on altitude a.s.l. and slope degree, affects local climate by altering climatic variables such as precipitation and air temperature, as well as the soil properties and the botanical composition (Hadjigeorgiou et al., 2005; Roukos et al., 2011a).

Previous studies have shown that the forage production of Greek grasslands ranges between wide limits and it's influenced by management, soil properties, successional stages and climatic conditions (Papanastasis, 1981; Papanastasis and Koukoulakis, 1988; Mountousis et al., 2008; Roukos et al., 2010; Mountousis et al., 2011; Roukos et al., 2011a; 2011b; Mpokos et al., 2014; Karatassiou, 2016).

Little is known about the species composition and forage production of the subalpine grasslands in Greece. Even less comparative data are available concerning the impact of altitude zone across a subalpine mountain side on soil properties, species botanical components and forage production, which cannot fulfil forage demands of ruminants during summer and consequently limits their productivity.

The aim of this study was to determine the effect of altitudinal zone on soil properties, species composition and forage production, along a subalpine mountain side divided into three altitudinal zones based on the time they grazed by livestock.

\section{Materials and methods}

\section{Study area}

The research was conducted during the period 2013 - 2015 in 'Kostilata' subalpine grassland (longitude $21.159210^{\circ}$, latitude $39.422238^{\circ}$ ) located in northwestern Greece, on Mount Tzoumerka. Grassland extended at an altitude ranging from $1100 \mathrm{~m}$ to $2393 \mathrm{~m}$ a.s.l. and grazed by eight transhumant livestock flocks, from May to October, with 3,600 sheep.

The wider area is important for species associated with alpine and subalpine grasslands and due to its characteristic vegetation communities above the timber line in which many Greek endemics as well as rare and threatened plant taxa exist. Although 
the Kostilata subalpine grassland (Fig. 1) is known for its traditional transhumant livestock system, it seems that is intensively grazed suffering from high stocking rate values.

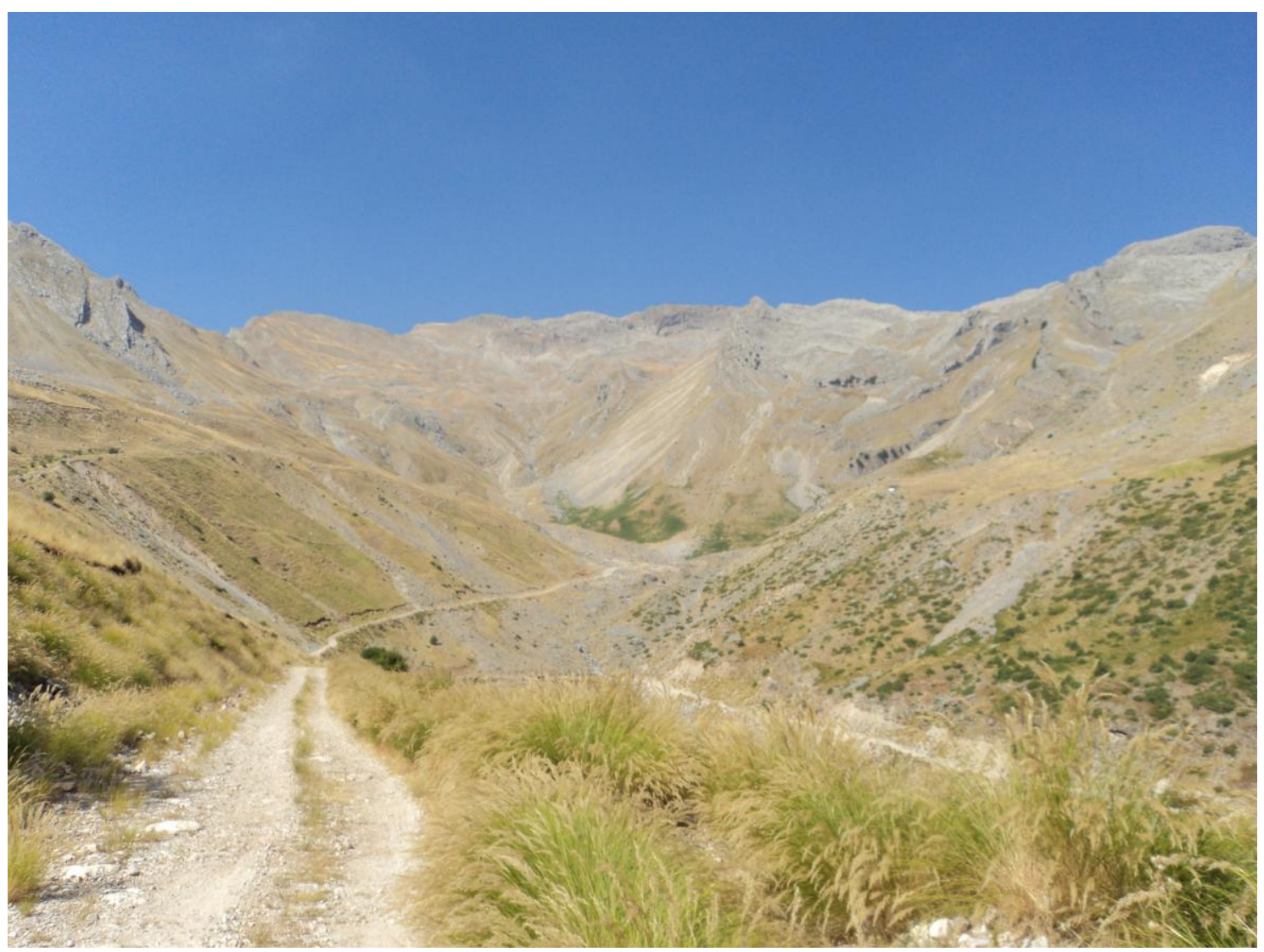

Figure 1. General view of Kostilata subalpine grassland.

\section{Forage samples}

During April 2013, 60 sites with eastern -southeastern aspects, which represented typical grassland conditions, were selected for monthly sampling. Sites were classified into three altitudinal zones based on altitude a.s.l.: lower $(1100-1400 \mathrm{~m})$, middle $(1401-1800 \mathrm{~m})$ and upper $(1801-2393 \mathrm{~m})$ according to seasonal use of the sheep flocks. In each zone, twenty experimental plots of $4 \mathrm{~m} \mathrm{X} 5 \mathrm{~m}$ each, were fenced to avoid grazing during the experimental period. The forage production was measured at monthly basis by harvesting the above ground biomass of the vegetation from five randomly $0.5 \mathrm{~m} \times 0.5 \mathrm{~m}$ quadrats in each protected plots. Those plant species present in the quadrats with a cover value above $15 \%$ were considered as dominant plant species (Table 1). Samples were immediately placed into individual paper bags, transported to the laboratory and manually separated into three plant groups: grasses, legumes and other forbs. Then, to determine the dry weight in each plant group, the samples were placed in an oven for 48 hours at $60{ }^{\circ} \mathrm{C}$ (Deinum and Maasen, 1994). 
Table 1. Plant species with a frequency of occurrence in herbage higher than $15 \%$ at blooming stage in each altitudinal zone.

\begin{tabular}{|c|c|c|c|c|c|}
\hline \multirow{2}{*}{$\begin{array}{l}\text { Botanical } \\
\text { Group }\end{array}$} & \multirow{2}{*}{ Species } & \multirow{2}{*}{ Life Form } & \multicolumn{3}{|c|}{ Altitudinal Zone } \\
\hline & & & Lower & Middle & Upper \\
\hline Grasses & Agrostis stolonifera, L. & Perennial & $\bullet$ & $\bullet$ & $\bullet$ \\
\hline Grasses & Alopecurus gerardii Vill & Perennial & & $\bullet$ & $\bullet$ \\
\hline Grasses & Alopecurus pratensis L. & Perennial & $\bullet$ & • & $\bullet$ \\
\hline Grasses & Anthoxanthum odoratum L. & Perennial & $\bullet$ & $\bullet$ & • \\
\hline Grasses & Arrhenatherum elatius (L) Beauv & Perennial & $\bullet$ & • & \\
\hline Grasses & Brachypodium pinnatum (L.) P. Beauv & Perennial & $\bullet$ & & \\
\hline Grasses & Briza media $\mathrm{L}$. & Perennial & $\bullet$ & $\bullet$ & \\
\hline Grasses & Bromus fibrosus Hack & Perennial & & • & • \\
\hline Grasses & Bromus hordeaceus L. & Annual/Biennial & $\bullet$ & - & $\bullet$ \\
\hline Grasses & Bromus sterilis L. & Annual & $\bullet$ & • & $\bullet$ \\
\hline Grasses & Bromus tectorum L. & Annual & & • & • \\
\hline Grasses & Calamagrostis varia Host & Perennial & & & $\bullet$ \\
\hline Grasses & Cynosurus cristatus L. & Perennial & $\bullet$ & $\bullet$ & \\
\hline Grasses & Dactylis glomerata L. subsp. glomerata & Perennial & • & • & • \\
\hline Grasses & Dasypyrum villosum L. P. Candagry & Annual & $\bullet$ & $\bullet$ & \\
\hline Grasses & Deschampsia flexuosa $\mathrm{L}$. Trin & Perennial & & - & • \\
\hline Grasses & $\begin{array}{l}\text { Festuca alpina Suter subsp. briquetii } \\
\text { (St-Yves ex Litard.) Markgr.-Dannenb. }\end{array}$ & Perennial & & • & • \\
\hline Grasses & Festuca arundinacea Schreb & Perennial & $\bullet$ & - & \\
\hline Grasses & Festuca heterofhylla Lam & Perennial & $\bullet$ & $\bullet$ & \\
\hline Grasses & Festuca ovina $\mathrm{L}$. & Perennial & $\bullet$ & $\bullet$ & • \\
\hline Grasses & Festuca rubra L. & Perennial & & $\bullet$ & $\bullet$ \\
\hline Grasses & Festuca sancta Meld & Perennial & $\bullet$ & $\bullet$ & \\
\hline Grasses & Festuca varia Haenke & Perennial & $\bullet$ & $\bullet$ & \\
\hline Grasses & Lolium multiflorum $\mathrm{L}$. & Annual & $\bullet$ & - & \\
\hline Grasses & Lolium perenne L. & Perennial & $\bullet$ & $\bullet$ & \\
\hline Grasses & Lolium rigidum Gaudin subsp. rigidum. & Annual & $\bullet$ & & \\
\hline Grasses & Phleum alpinum $\mathrm{L}$. & Perennial & & $\bullet$ & - \\
\hline Grasses & Phleum montanum C. Koch & Perennial & & $\bullet$ & $\bullet$ \\
\hline Grasses & Poa alpine L. & Perennial & & $\bullet$ & $\bullet$ \\
\hline Grasses & Poa bulbosa L. & Perennial & & $\bullet$ & \\
\hline Grasses & Poa nemoralis L. & Perennial & & $\bullet$ & • \\
\hline Grasses & Poa pratensis L. & Perennial & & $\bullet$ & • \\
\hline Grasses & Sesleria argentea Savi & Perennial & & $\bullet$ & \\
\hline Grasses & $\begin{array}{l}\text { Stipa pennata L. subsp. pulcherrima (C. } \\
\text { Koch) Freitag }\end{array}$ & Perennial & $\bullet$ & $\bullet$ & \\
\hline Grasses & $\begin{array}{l}\text { Koeleria lobata (Bieb.) Roemer \& } \\
\text { Schultes. }\end{array}$ & Perennial & $\bullet$ & $\bullet$ & \\
\hline Legumes & $\begin{array}{l}\text { Anthyllis vulneraria L. subsp. Pindicola } \\
\text { Cullen }\end{array}$ & Perennial & $\bullet$ & $\bullet$ & \\
\hline Legumes & Lathyrus aphaca L. & Annual & • & - & - \\
\hline Legumes & Lotus aegaeus B. & & & • & $\bullet$ \\
\hline Legumes & Lotus corniculatus L. & Perennial & $\bullet$ & $\bullet$ & \\
\hline Legumes & Lotus tenuis Waldst. \& Kit. ex Willd. & Perennial & $\bullet$ & - & • \\
\hline
\end{tabular}




\begin{tabular}{|c|c|c|c|c|c|}
\hline \multirow{2}{*}{$\begin{array}{l}\text { Botanical } \\
\text { Group }\end{array}$} & \multirow{2}{*}{ Species } & \multirow{2}{*}{ Life Form } & \multicolumn{3}{|c|}{ Altitudinal Zone } \\
\hline & & & Lower & Middle & Upper \\
\hline Legumes & Trifolium arvense $\mathrm{L}$. & Annual & $\bullet$ & $\bullet$ & \\
\hline Legumes & Trifolium repens $\mathrm{L}$. & Perennial & $\bullet$ & $\bullet$ & $\bullet$ \\
\hline Legumes & Vicia pubescens (DC.) Link & Annual & & $\bullet$ & $\bullet$ \\
\hline Legumes & Medicago arabica $\mathrm{L}$. & & - & • & $\bullet$ \\
\hline Forbs & $\begin{array}{l}\text { Chenopodium bonus-henricus L. syn. } \\
\text { Blitum bonus-henricus (L.) Rchb. }\end{array}$ & Perennial & & $\bullet$ & - \\
\hline Forbs & Scandix macrorhyncha C. A. Meyer & Annual & $\bullet$ & $\bullet$ & \\
\hline Forbs & Arum maculatum (L.) & Perennial & & & $\bullet$ \\
\hline Forbs & $\begin{array}{l}\begin{array}{l}\text { Achillea millefolium } \\
\text { millefolium }\end{array} \\
\text { L. }\end{array}$ subsp. & Perennial & - & • & $\bullet$ \\
\hline Forbs & Bellis perennis $\mathrm{L}$. & Perennial & - & - & \\
\hline Forbs & Carduus tmoleus Boiss. & Perennial & & $\bullet$ & $\bullet$ \\
\hline Forbs & Crhysanthemum segetum $\mathrm{L}$. & & & $\bullet$ & \\
\hline Forbs & Anchusa azurea Mill. & Perennial & & • & $\bullet$ \\
\hline Forbs & Echium italicum $(\mathrm{L})$. & Biennial & $\bullet$ & $\bullet$ & \\
\hline Forbs & $\begin{array}{l}\text { Myosotis alpestris F. W. Schmidt subsp. } \\
\text { suaveolens (Waldst. \& Kit. ex Willd.) } \\
\text { Strid }\end{array}$ & $\begin{array}{l}\text { Biennial } \\
\text { Perennial }\end{array}$ & $\bullet$ & $\bullet$ & \\
\hline Forbs & Sinapis arvensis $\mathrm{L}$. & Annual & $\bullet$ & $\bullet$ & \\
\hline Forbs & Capsella bursa-pastoris $\mathrm{L}$. & & $\bullet$ & $\bullet$ & $\bullet$ \\
\hline Forbs & $\begin{array}{l}\text { Capsella grandiflora (Fauche \& } \\
\text { Chaub.) Boiss. }\end{array}$ & Annual & $\bullet$ & - & \\
\hline Forbs & Campanula albanica Witasëk & Perennial & & $\bullet$ & $\bullet$ \\
\hline Forbs & Cerastium spp. & & $\bullet$ & $\bullet$ & \\
\hline Forbs & Arabis alpina $\mathrm{L}$. & $\begin{array}{l}\text { Biennial, } \\
\text { Perennial }\end{array}$ & & $\bullet$ & $\bullet$ \\
\hline Forbs & Euphorbia herniariifolia Wild. & Perennial & & $\bullet$ & $\bullet$ \\
\hline Forbs & Euphorbia myrsinites L. & Perennial & & $\bullet$ & $\bullet$ \\
\hline Forbs & $\begin{array}{l}\text { Erodium cicutarium (L.) L'Hér. ex } \\
\text { Aiton }\end{array}$ & Annual & - & - & \\
\hline Forbs & $\begin{array}{l}\text { Pteridium aquillinum (L.) Kuhn subsp. } \\
\text { aquillinum }\end{array}$ & Annual & $\bullet$ & - & \\
\hline Forbs & Crocus veluchensis Herbert & Perennial & & - & $\bullet$ \\
\hline Forbs & Luzula campestris (indica) (L.) DC. & Perennial & & $\bullet$ & $\bullet$ \\
\hline Forbs & Marrubium velutinum Sibth \& Sm. & Perennial & & $\bullet$ & $\bullet$ \\
\hline Forbs & Menta longifolia (L.) Hudson & Perennial & $\bullet$ & $\bullet$ & $\bullet$ \\
\hline Forbs & Thymus striatus Vahl & Perennial & $\bullet$ & $\bullet$ & \\
\hline Forbs & $\begin{array}{l}\text { Fritillaria thessala (Boiss.) Kamari } \\
\text { subsp. ionica (Halácsy) Kamari }\end{array}$ & Perennial & & - & \\
\hline Forbs & Muscari comosum (L.) Mill. & Perennial & $\bullet$ & $\bullet$ & $\bullet$ \\
\hline Forbs & Ornithogalum oligophyllum E.D.Clarke & Perennial & $\bullet$ & $\bullet$ & $\bullet$ \\
\hline Forbs & Ornithogalum sibthorpii Greuter & Perennial & $\bullet$ & $\bullet$ & $\bullet$ \\
\hline Forbs & Scilla nivalis Boiss (Scilla bifolia L.) & Perennial & $\bullet$ & $\bullet$ & $\bullet$ \\
\hline Forbs & Dactylorhiza saccifera (Brongn.) Soo & Perennial & & $\bullet$ & \\
\hline Forbs & Papaver rhoeas L. (Papaver; anemone) & Annual & & - & \\
\hline Forbs & $\begin{array}{l}\text { Plantago atrata ssp. Graeca (Halacsy) } \\
\text { Holub. }\end{array}$ & Perennial & - & - & $\bullet$ \\
\hline Forbs & Plantago holosteum Scop. & Perennial & $\bullet$ & $\bullet$ & $\bullet$ \\
\hline
\end{tabular}




\begin{tabular}{|c|c|c|c|c|c|}
\hline \multirow{2}{*}{$\begin{array}{c}\text { Botanical } \\
\text { Group }\end{array}$} & \multirow{2}{*}{ Species } & \multirow{2}{*}{ Life Form } & \multicolumn{3}{|c|}{ Altitudinal Zone } \\
\hline & & & Lower & Middle & Upper \\
\hline Forbs & Plantago lanceolata $\mathrm{L}$. & Perennial & $\bullet$ & $\bullet$ & $\bullet$ \\
\hline Forbs & $\begin{array}{l}\text { Polygala nicaeensis K. Koch subsp. } \\
\text { mediterranea Chodat }\end{array}$ & Perennial & & $\bullet$ & \\
\hline Forbs & Rumex acetosella L. & Perennial & & $\bullet$ & $\bullet$ \\
\hline Forbs & Rumex alpinus $\mathrm{L}$. & Perennial & & • & $\bullet$ \\
\hline Forbs & Primula veris $\mathrm{L}$. & Perennial & & $\bullet$ & \\
\hline Forbs & $\begin{array}{l}\text { Primula vulgaris Huds. бov. P. acaulis } \\
\text { (L.) Hill }\end{array}$ & Perennial & & - & \\
\hline Forbs & $\begin{array}{l}\text { Helleborus odorus Waldst. \& Kit. } \\
\text { Subsp. cyclophyllus (A. Braun) Strid }\end{array}$ & Perennial & & - & \\
\hline Forbs & Ranunculus brevifolius Ten. & Perennial & • & - & • \\
\hline Forbs & Ranunculus psilostachys Griseb. & Perennial & $\bullet$ & - & \\
\hline Forbs & Ranunculus repens $\mathrm{L}$. & Perennial & $\bullet$ & $\bullet$ & $\bullet$ \\
\hline Forbs & Ranunculus spruneranus Boiss. & Perennial & • & - & \\
\hline Forbs & Scrophularia canina $\mathrm{L}$. & Perennial & & $\bullet$ & $\bullet$ \\
\hline Forbs & Verbascum densiflorum Bertol. & Biennial & & $\bullet$ & $\bullet$ \\
\hline Forbs & Urtica dioica var. dioica $\mathrm{L}$. & Perennial & - & - & $\bullet$ \\
\hline Forbs & Valeriana officinalis & Perennial & $\bullet$ & $\bullet$ & \\
\hline Forbs & Viola epirota (Halacsy) Raus & Perennial & $\bullet$ & - & \\
\hline
\end{tabular}

\section{Soil samples analysis}

In each plot, soil samples were collected from the surface layer $(0-30 \mathrm{~cm})$ in June 2013 and chemical analyses were performed in order to evaluate certain physical and chemical properties of the soil. Prior to soil physical and chemical analyses, all samples were air-dried at room temperature and passed through a $2 \mathrm{~mm}$ soil sieve. Soil particle size distribution was determined with the hydrometer method (Gee and Or, 2002) and organic matter by the Walkley Black method (Nelson and Sommers, 1996). The $\mathrm{pH}$ measurements were assessed in a water suspension using a soil/solution ratio of $1 / 2$ (Thomas, 1996) and available $\mathrm{P}(\mathrm{ppm})$ was evaluated with the Olsen method (Kuo, 1996).

\section{Climatic data}

For our study, three automated weather stations (Onset HOBO weather station) were installed (one in each altitudinal zone) to record local precipitation and temperature fluctuations among the zones throughout the three years of the study (Fig. 2).

\section{Calculations}

Grazing capacity was calculated according to Holechek et al. (2010) taking into account the following assumptions: (a) the Animal Unit (AU) was defined as one 50$\mathrm{kg}$ ewe and lamb (Minson, 1990); (b) forage intake by a ewe was $1.0 \mathrm{~kg}$ DM per $50 \mathrm{~kg}$ of liveweight (NRC, 1985); (c) sheep grazed only in grasslands for a period of four to five months in the grassland area; (d) the proper use factors were $50 \%$ for the grasslands; and (e) the average grazing livestock population of the Kostilata grassland, in AU, for the period of 2013-2015 was taken from data provided by local self- 
organized authority (Municipality of Central Tzoumerka), in which farmers pay for grassland utilization (rangeland right) to receive European Communities subsidies.
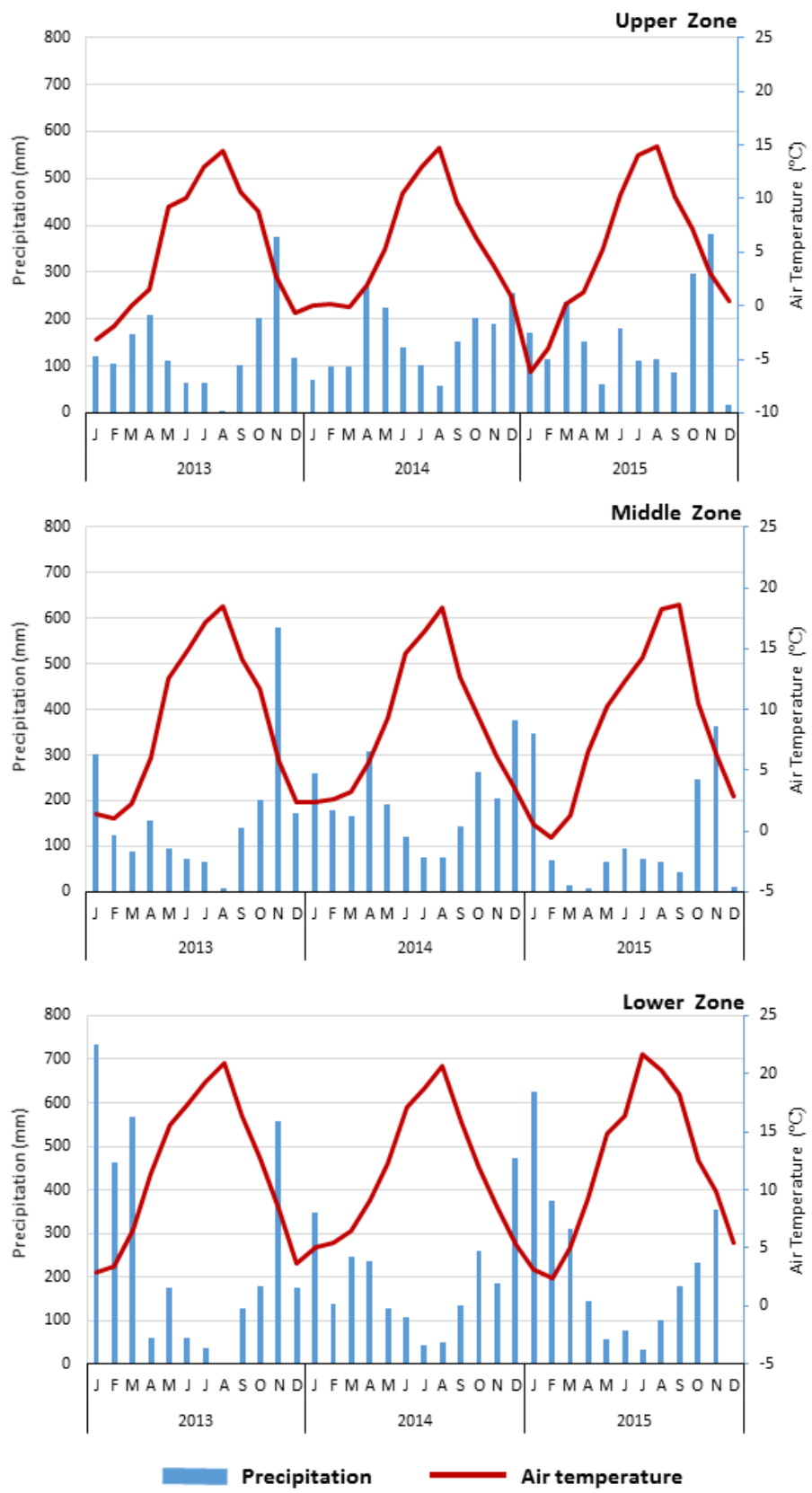

Figure 2. Monthly precipitation and mean monthly air temperature during 2013 - 2015.

Slope degree was extracted from the digital elevation model (DEM) of the study area (Fig. 3). The DEM obtained from Greek National Cadastre and Mapping Agency with a $5 \mathrm{~m} \times 5 \mathrm{~m}$ cell size was used in this study. Then, slope was divided into four levels, 0 $10 \%, 11-30 \%, 31-60 \%$, and $>61 \%$ and estimated grazing capacity was calculated following the suggested reductions in grazing capacity for different percentages of slope (Holechek, 1988). 


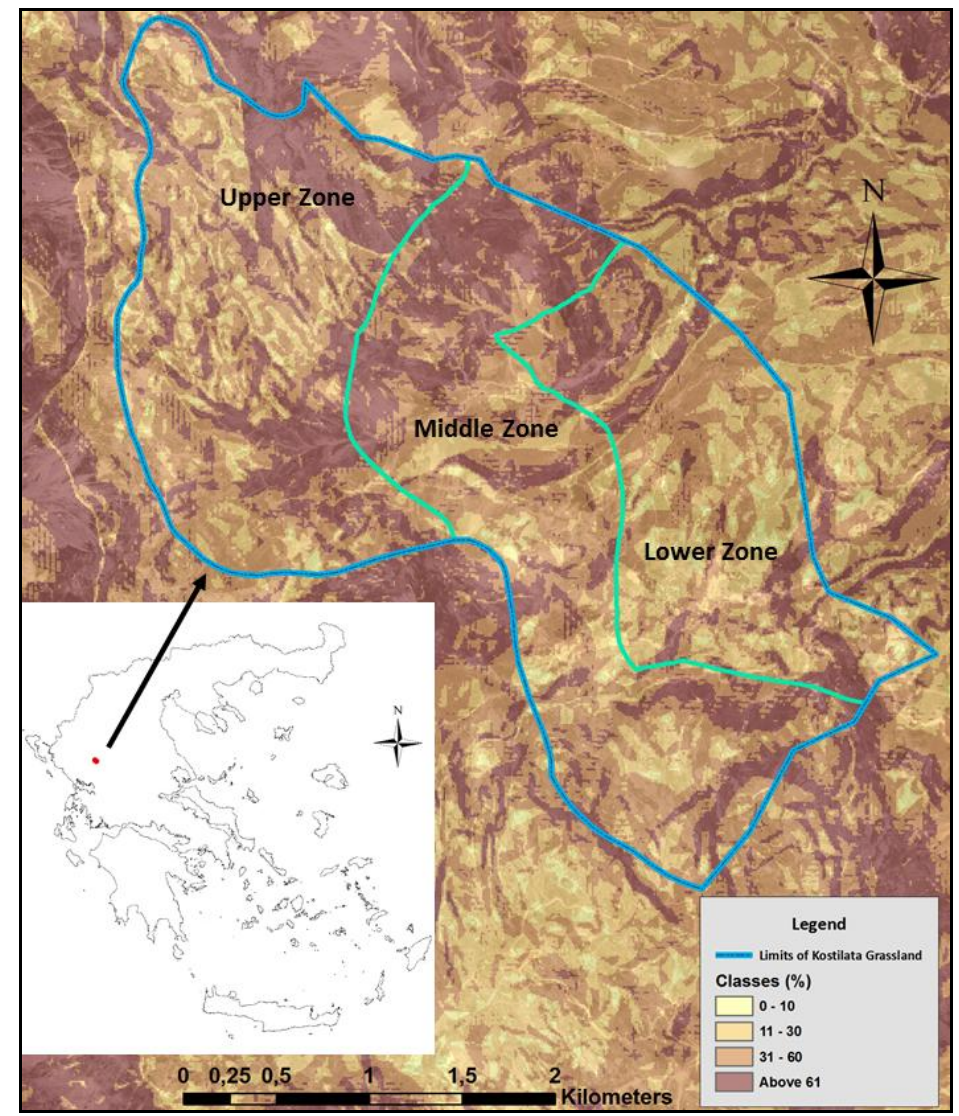

Figure 3. Slope map of the studied grassland area divided into four slope levels.

\section{Statistical analysis}

Statistical differences of climatic variables and soil properties were tested using Analysis of Variance (ANOVA). Least Square Differences (LSD) were used to determine significant differences among means when significant ANOVA results occurred $(\mathrm{p}<0.05)$.

Data of forage production and species composition were tested using a two-way analysis of variance with altitudinal zones $(n=3)$ as main plots and month of harvest $(n$ =5) as sub-plots (Snedecor and Cochran, 1980). The experimental plots and year of harvest were considered as random effects. The interaction altitudinal zone $\times$ month of harvest was significant $(\mathrm{p}<0.05)$; thus, analyses of variance were conducted among altitudinal zones and among altitudinal zones within month of harvest. Significant mean differences were detected using least square differences (Steel and Torrie, 1980). The Pearson's correlation was employed to examine relationships between climatic variables, soil properties, herbage production and altitude a.s.l.

\section{Results and Discussion}

\section{Climatic conditions}

Species composition and forage production are highly sensitive to climate variability and changes (Holechek et al., 2010). In the study area, the ombrothermic diagrams (Fig. 4) showed the absence of dry periods and consequently the plants species does not 
suffer from water stress periods especially in middle and upper zones. The mean monthly precipitation and air temperature were negatively correlated with altitude a.s.l. $(\mathrm{r}=-0.238 ; \mathrm{p}<0.01$ and $\mathrm{r}=-0.705 ; \mathrm{p}<0.01$, respectively). However, the temperature significantly $(\mathrm{p}<0.01)$ differed in the three altitudinal zones during the experimental period. The mean annual precipitation and temperature were significant higher $(\mathrm{p}<0.05)$ in the lower zone than in the middle and upper zones. In addition, significant difference in precipitation occurred between the lower and the other two altitudinal zones.
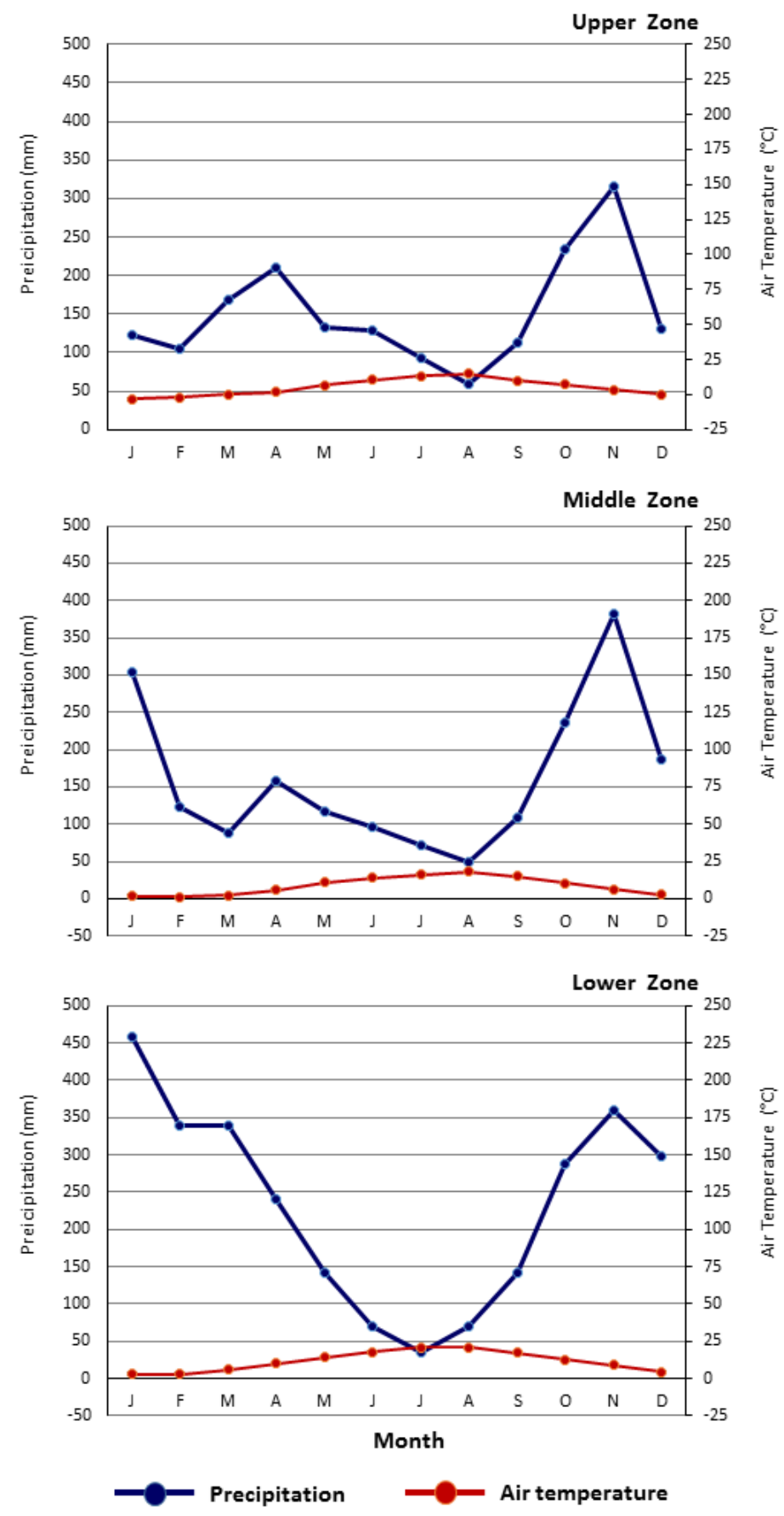

Figure 4. Obrothermic diagrams for lower, middle and upper zone based on 3-years average values of precipitation and air temperature. 
In the study area, it seems that the low air temperature is the main restrictive factor for plant growth and production because the higher amount of precipitation occurs during spring. On the other hand the cold temperatures of upper zone can influence plant productivity by delaying initiation of growth in spring (Sneva, 1982). This results is in agreement with the founding of Roukos et al. (2011a) and Mountousis et al. (2011) in northwestern Greece.

\section{Grassland vegetation}

In the 4 years of the experiment, the collected samples of forage production from Kostilata grassland consisted of 96 taxa which belong to 30 families. The most frequent family was the Poaceae with 35 species, followed by the Fabaceae with 9 species and Ranunculaceae and Liliaceae with 5 species (Table 1).

The subalpine grassland is dominated by perennial grasses, a finding that is in consistent with Papanastasis (1981) and Papanastasis et al. (2003). Grasses species have better adaptability to wide range of environmental conditions than legumes species which are influenced more by the low temperatures in winter and spring (Papanastasis et al., 2003; Holechek et al., 2010).

\section{Changes in species composition}

The contribution of each plant group in the overall forage botanical composition in relation to altitudinal zone and month of harvset is shown in Figure 5. The altitudinal zone and month of harvest significantly $(\mathrm{p}<0.05)$ affected the proportion of grasses, legumes and other forbs in forage composition. Over all altitudinal zones and sampling years, the major contribution to the forage mass was from grasses. Indeed, the participation of grasses in the species composition varied between $60.7 \%$ and $82.6 \%$ and it was significantly $(\mathrm{p}<0.05)$ higher in middle and upper zones than lower zone. On the other hand, the relative contribution of the legumes was higher $(\mathrm{p}<0.05)$ in the middle and upper than in lower zone. Furthermore, the proportion of other forbs was the highest $(\mathrm{p}<0.05)$ at upper zone.

The different contribution of the various plant groups is probably caused by the different stocking rate (Shakhane et al., 2013; Catorci et al., 2015; Lwiwski et al., 2015) and climatic and soil conditions (Vazquez-de-Aldana et al. 2000; Oztas et al.. 2003; Garamvölgyi and Hufnagel, 2013) between the three altitude zones (Tables $4 \& 6$ ).

\section{Forage Production and Grazing Capacity}

The altitudinal zone significantly affected $(\mathrm{p}<0.001)$ the forage production which fluctuated from $590 \mathrm{~kg} \mathrm{ha}^{-1}$ at upper zone to $1621 \mathrm{~kg} \mathrm{ha}^{-1}$ at middle zone (Table 2). Generally, forage production was negatively correlated $(\mathrm{p}<0.01)$ with altitude a.s.l.( $\mathrm{r}=-$ $0.296)$ and positively correlated with air temperature $(r=0.226)$. Thus, on average, forage production was the highest at lower zone and the lowest at upper zone. This finding show that a district step gradient along to altitude a.s.l. occurs and is in accordance with the results of Pérez Corona (1998), Vazquez-de-Aldana et al. (2000), Mountousis et al. (2011) and Roukos et al. (2011a), who found significant variations among altitudinal zones in rangelands of Spain and Greece. However, other studies (Papanastasis 1982, Mountousis et al. 2008) found that forage production increases with the altitude a.s.1., a finding that in not confirmed with the results of this study. This difference may due to high precipitation at all zones and different soil properties in the study area. 

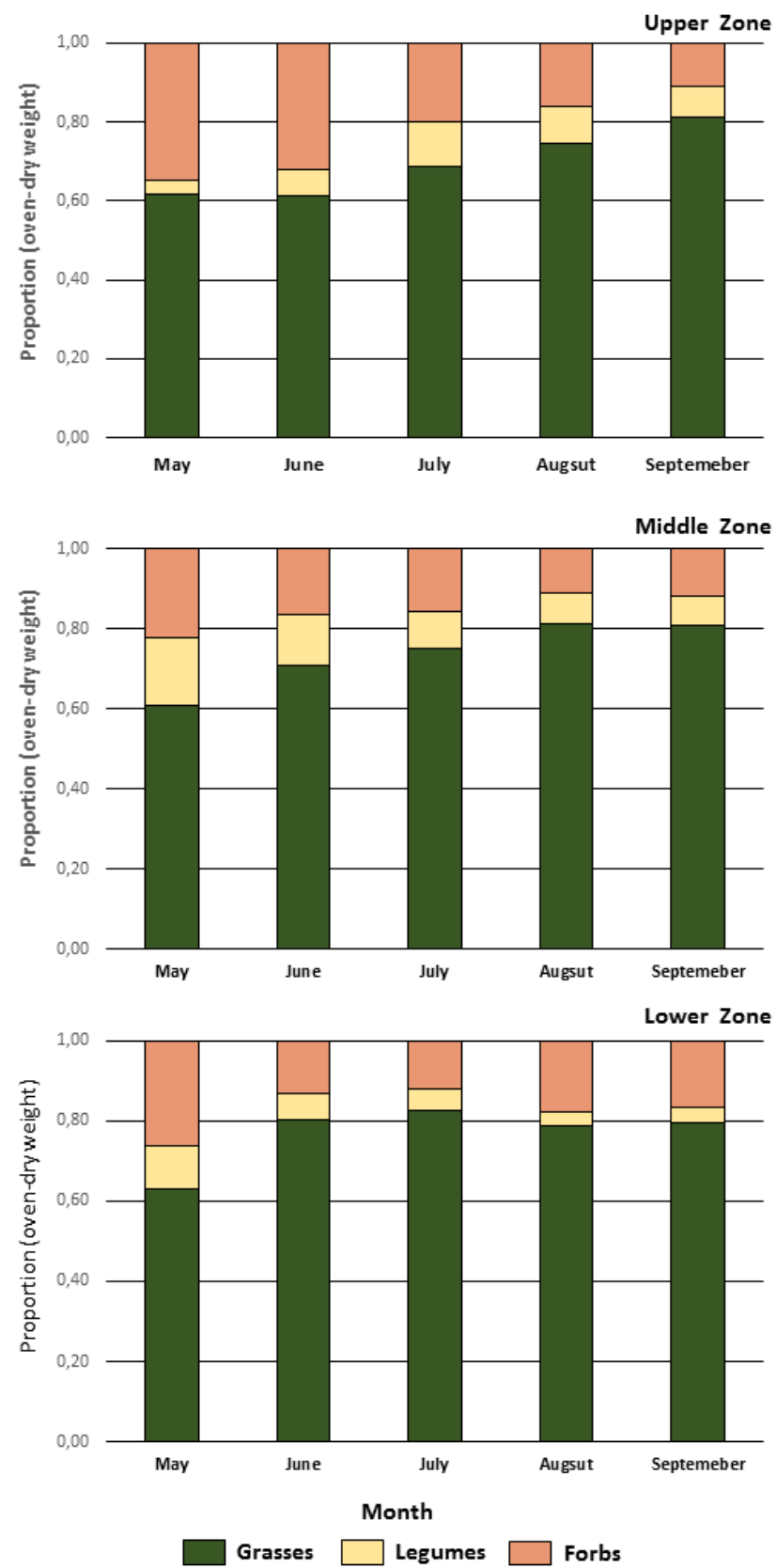

Figure 5. Proportion (oven dry weight) of botanical groups (grasses, legumes and forbs) in the herbage mass in relation to altitudinal zone and month of harvest.

For each altitudinal zone, the stocking rate and the grazing capacity values are shown in Table 3. The overall estimated grazing capacity of grassland (15400 AUMs), without slope adjustments, slightly exceeds the current stocking rate (14400 AUMs). The applied stocking rate, however, was fluctuated above the estimated grazing capacity at lower and upper zones. On the other hand, if slope adjustment will be taking into account, it is assumed that grazing capacity represents only the $40 \%$ of the current stocking rate. The results of grazing capacity estimation, suggests that the grassland is overgrazed at all altitudinal zones. 
Table 2. Monthly and altitudinal zone means of herbage production ( $\left.\mathrm{kg} D \mathrm{DM} \mathrm{h}^{-1}\right)$.

\begin{tabular}{c|c|c|c|c|c|c|c|c}
\hline Zone & May & June & July & August & September & Mean & s.e.m. & Sig. \\
\hline Lower & 1.403 & 1.690 & 1.539 & 1.068 & 977 & 1.336 & 81 & $* * *$ \\
Middle & 736 & 1.554 & 1.621 & 1.137 & 1.146 & 1.239 & 74 & $* * *$ \\
Upper & & 590 & 1.018 & 1.105 & 1.003 & 940 & 88 & $* * *$ \\
Mean & \multirow{2}{*}{1070} & 1.278 & 1.393 & 1.103 & 1.042 & 1.172 & & \\
s.e.m. & & 96 & 93 & 78 & 62 & 49 & & \\
Sig. & $* * *$ & $* * *$ & $* * *$ & NS & $* *$ & $* * *$ & & \\
\hline
\end{tabular}

Note: Different letters between zones denote significant differences $(\mathrm{P}<0.05)$

s.e.m. Standard error of the mean

Sig. Significant level, *: $\mathrm{p}<0.05, * *: \mathrm{p}<0.01, * * *: \mathrm{p}<0.001$

Table 3. Stocking rate and grazing capacity of the studied grassland in the three altitudinal zones.

\begin{tabular}{c|c|c|c|c|c|c|c}
\hline $\begin{array}{c}\text { Altitudinal } \\
\text { Zone }\end{array}$ & $\begin{array}{c}\text { Area } \\
\text { (ha) }\end{array}$ & $\begin{array}{c}\text { Production } \\
\text { (kg DM / } \\
\text { ha) }\end{array}$ & $\begin{array}{c}\text { Grazing } \\
\text { period } \\
\text { (months) }\end{array}$ & $\begin{array}{c}\text { Animal } \\
\text { Units } \\
\text { (AU) }\end{array}$ & $\begin{array}{c}\text { Stocking } \\
\text { rate } \\
\text { (AUM) }\end{array}$ & $\begin{array}{c}\text { Grazing Capacity (AUM) } \\
\text { Sithout } \\
\text { adjustment }\end{array}$ & $\begin{array}{c}\text { With slope } \\
\text { adjustment }\end{array}$ \\
\hline Lower & 2.502 & 1.690 & 6 & 1430 & 5720 & 4699 & 2024 \\
Middle & 3.729 & 1.621 & 5 & 1070 & 4280 & 6717 & 2311 \\
Upper & 3.523 & 1.105 & 4 & 1100 & 4400 & 3984 & 1311 \\
Sum & 9.754 & & & 3600 & 14400 & 15400 & 5646 \\
\hline
\end{tabular}

Continued use of stocking rates above the grazing capacity generally leads to grassland degradation and decline in production per animal (Hunt et al., 2014). The overgrazing disappears the most palatable species and can result in significant changes in forage production, floristic composition, diversity, and the recycling of nutrients in the grasslands' ecosystem (Papanastasis et al 2002, Zhang and Dong, 2009, Catorci et al., 2015; Kairis et al. 2015). Furthermore, as slope degree increases with altitude a.s.1., an increased soil erosion hazard occurs and a further reduce in grazing capacity it is expected (Kairis et al. 2015).

\section{Slope degree and soil properties}

According to surface analysis, the slope degree of mountain grasslands vary according to altitudinal zone (Table 4). The lower zone is dominated by gentle slopes as the $37 \%$ of the total grassland area located in slope degree up to $30 \%$. However, slope degree increases in middle and upper altitudinal zones. Thus, the vast majority of total grassland area is located in slope degree over $30 \%$.

The soil textural fractions varied significantly $(\mathrm{p}<0.05)$ with altitudinal zone (Table 5). Clay and silt content were significantly $(\mathrm{p}<0.05)$ lower and higher, respectively, in lower zone than middle and upper zones.

The high mean annual precipitation, resulting from the orographic effect (Dotsika et al., 2010), has probably affected the soil sand content. The upper zone characterized by more steep slopes, high sand content and high precipitation, conditions that encourage 
soil erosion more than the other altitudinal zones. This has leaded to selectively transport clay and silt fractions from the higher altitudes down the slopes leaving behind sand fractions (Yimer et al., 2006). In high precipitation environments too much precipitation can result in nutrient leaching in sandy soils (Anderson et al., 1998) and soil stability is influenced by secondary clay minerals (Manyeverea et al., 2016). Additionally, as slope degree increases less water enters the soil and more runs off as overland flow. In this situation, when grazing pressure increases in mountain pastures, soils will be susceptible to degradation from processes such as runoff and erosion (Sheatch et al., 1998).

In mountainous areas, significant variations in soil texture in relation to topography have been reported both in Mediterranean basin (Badano et al., 2005; Acosta et al.. 2008; Oyonarte et al.. 2008; Roukos et al.. 2011b) and other countries (Oztas et al.. 2003; Yimer et al.. 2006; Guzman and Al-Kaisi, 2011). Our results concur with them.

Soil $\mathrm{pH}$ is considered to be an important factor that determines the floristic diversity and composition of grasslands (Critchley et al., 2002). The soil $\mathrm{pH}$ values showed significant variation $(\mathrm{p}<0.05)$ with respect to altitudinal zone (Table 5). The overall mean soil $\mathrm{pH}$ values ranges from 5.4 to 5.9 among all zones. Therefore, soils characterized are strongly acid in upper and middle zones and moderately acid in lower zone.

Table 4. The distribution of slope classes in relation to altitudinal zone according to surface analysis.

\begin{tabular}{l|c|c|c|c}
\hline \multirow{2}{*}{ Altitudinal Zone } & \multicolumn{4}{|c}{ Slope groups (\%) } \\
\cline { 2 - 5 } & $\mathbf{0 ~ - ~ 1 0}$ & $\mathbf{1 1 ~ - ~ 3 0}$ & $\mathbf{3 1 ~ - ~ 6 0}$ & Abobe 60 \\
\hline Lower & $6 \%$ & $31 \%$ & $38 \%$ & $25 \%$ \\
Middle & $4 \%$ & $20 \%$ & $43 \%$ & $34 \%$ \\
Upper & $2 \%$ & $16 \%$ & $42 \%$ & $40 \%$ \\
Sum & $4 \%$ & $21 \%$ & $41 \%$ & $34 \%$ \\
\hline
\end{tabular}

Table 5. Soil properties in relation to altitudinal zone.

\begin{tabular}{c|c|c|c|c|c|c}
\hline Zone & $\begin{array}{c}\text { Sand } \\
(\%)\end{array}$ & $\begin{array}{c}\text { Silt } \\
(\%)\end{array}$ & $\begin{array}{c}\text { Clay } \\
(\%)\end{array}$ & $\mathrm{pH}$ & $\begin{array}{c}\text { Organic } \\
\text { matter } \\
(\%)\end{array}$ & $\begin{array}{c}\text { Available P } \\
\left(\mathrm{mg} \mathrm{kg}^{-1}\right)\end{array}$ \\
\hline Lower & $43.9 \mathrm{a}$ & $38.3 \mathrm{a}$ & $17.8 \mathrm{a}$ & $5.9 \mathrm{a}$ & $6.9 \mathrm{a}$ & $4.3 \mathrm{a}$ \\
Middle & $48.7 \mathrm{~b}$ & $35.1 \mathrm{~b}$ & $16.2 \mathrm{ab}$ & $5.5 \mathrm{~b}$ & $6.7 \mathrm{ab}$ & $5.6 \mathrm{a}$ \\
Upper & $52.9 \mathrm{c}$ & $33.9 \mathrm{~b}$ & $13.2 \mathrm{~b}$ & $5.4 \mathrm{~b}$ & $5.5 \mathrm{~b}$ & $6.2 \mathrm{~b}$ \\
s.e.m. & 1.45 & 1.17 & 1.59 & 0.17 & 0.48 & 0.71 \\
Sig. & $* * *$ & $*$ & $*$ & $*$ & $*$ & $*$ \\
\hline
\end{tabular}

Note: Different letters between zones denote significant differences $(\mathrm{P}<0.05)$

s.e.m. Standard error of the mean

Sig. Significant level, *: p<0.05, **: $\mathrm{p}<0.01, * * *: \mathrm{p}<0.001$

Acid soils are most often found in high precipitation areas as leaching of bases is more extensive (Ellis and Mellor, 1995). Consequently, low values of soil $\mathrm{pH}$ among altitudinal zones probably resulted from the fact that increasing altitude increases slope degree and thus, combined with the high precipitation, can cause increased leaching and 
reduction in soluble base cations leading to higher $\mathrm{H}+$ activity and registered as decreased pH (Rezaei and Gilkes 2005).

Significant variation in soil $\mathrm{pH}$ among topographic aspects also found by Oztas et al. (2003), Yimer et al. (2006), Oyonarte et al. (2008) and Roukos et al. (2011b).

Soil organic matter content was influenced $(\mathrm{p}<0.05)$ by altitudinal zone. The mean soil organic matter varied between $5.5 \%$ at upper to $6.9 \%$ at lower zone (Table 3) and showed a significant $(\mathrm{p}<0.05)$ negative correlation with altitude a.s.l. $(\mathrm{r}=-0.394)$ and positive one with clay content $(\mathrm{r}=0.282)$.

It seems that the high precipitation and the more steep slopes of middle and upper zones have favored organic matter accumulation in lower zone because of runoff and erosion. Simiral results also demonstrated by Roukos et al. (2011b). Moreover, the high organic matter content have been directly related to higher surface cover rates in lower zone and because of higher amounts of available water content for plant growth (Oztas et al., 2003).

The concentrations of organic matter of all altitudinal zones were greater than those reported from Roukos et al. (2011b) on rangeland soils located near the study area. This result could be attributed to lower mean annual temperatures in all altitudinal zones and is consistent with the findings from Kirschbaum (1995, 2006) who reported that temperature influences organic matter accumulation, which increases with precipitation and decreases with temperature (Burke et al., 1989) as temperature is a key factor controlling the rate of decomposition of plant residues (Paré et al., 2006).

In grassland management, it is important to maintain proper levels of soil organic matter to sustain grassland soil productivity (Holechek et al., 2010). An additional decline in soil organic matter due to erosion at upper zone will significantly reduce the $\mathrm{N}$ supply and resulting in a deterioration of soil physical condition leading to yield reduction (Greer et al., 1996).

The result of this study is in agreement with results from other studies indicating that soil organic matter decreases from lowlands to uplands (Oztas et al.. 2003) and that tends to increase as the clay content increases (Prasad and Power, 1997; Roukos et al., 2011b).

The amounts of soil available phosphorus did not show significant variations among altitudinal zones (Table 5). Available $\mathrm{P}$ was significantly $(\mathrm{p}<0.05)$ higher at upper zone. However, the higher available $\mathrm{P}$ levels suggest that more $\mathrm{P}$ is present in forms available for plant uptake which may be probably be due to increased phosphorus fixation and lower rates of decomposition as suggested by Yimer et al. (2006).

\section{Conclusions}

In high rainfall subalpine mountainous environments, the altitudinal gradient strongly affects climatic conditions, soil properties, herbage production, and species composition of grasslands. In the studied grassland, the stocking rate exceeds the grazing capacity and thus a new management plan involving rotational grazing and the implementation of supplemental nutrition could be considered in order to sustain grassland production and avoid further degradation of grasslands ecosystem.

Acknowledgements. This study was supported and co-financed by the European Union (European Fund of Regional Development) and National resources in the framework of the Regional Operational Program "Thessaly - Central Greece - Epirus". 


\section{REFERENCES}

[1] Acosta, B., L. Sánchez-Jardón, A. del Pozo, E. Garcia-Ibáñez, Casado, M. A., Montalvo, J., Pineda, F.D. (2008): Grassland species composition and morpho-functional traits along an altitudinal gradient in a Mediterranean environment: Relationship with soil water availability and evaporative dynamic. - Acta Oecologica 34: 26-37.

[2] Anderson, G., Filleryl, I., Dunim, F., Dolling, P., Asseng, S. (1998): Nitrogen and water flows under pasture-wheat and lupin-wheat rotations in deep sands in Western Australia. 2. Drainage and nitrate leaching. - Australian Journal of Agrocultural Research 49(30): 345-362.

[3] Badano, E.I., Cavieres, L.A., Molina-Montenegro, M.A., Quiroz, C.L. (2005): Slope aspect influences plant association patterns in the Mediterranean matorral of central Chile. - Journal of Arid Environments 62: 93-108.

[4] Burke, I. C., Elliot E.T., Cole C.V. (1995): Influence of macroclimate, landscape position and management on soil organic matter in agroecosystems. - Ecological Applications 5: 124-131.

[5] Catorci, A., Tardella, F.M., Piermarteri, K., Pennesi, R., Malatesta, L., Corazza, M., Scocco, P. (2015): Effect of red deer grazing on alpine hay meadows: Biodiversity and management implications - Applied Ecology and Environmental Research 14(2):301-318.

[6] Chatzitheodoridis, F., Michailidis, A., Theodossiou, G. (2007): Comparative analysis of sheep-goat farming in a typical Greek island: economy and environment. Applied Economics and Policy Analysis 1(1-2): 191-200.

[7] Critchley, C.N.R., Chambers, B.J., Fowbert, J. A., Bhogal, A., Rose, S.C., Sanderson, R.A. (2002): Plant species richness, functional type and soil properties of grasslands and allied vegetation in English Environmentally Sensitive Areas. - Grass and Forage Science 57: 82-92.

[8] Dafis S., Papastergiadou, E., Lazaridou, T., Tsiafouli, M. (2001): Technical Guide for Identification, Description and Mapping of Habitat Types of Greece. - Greek BiotopeWetland Centre (EKBY) Publishing, Thessaloniki.

[9] Deinum, B., Maassen, A. (1994): Effects of drying temperature on chemical composition and in vitro digestibility of forages. - Animal Feed Science and Technology 46:75-86.

[10] Dotsika, E., Lykoudis, S., Poutoukis, D. (2010): Spatial distribution of the isotopic composition of precipitation and spring water in Greece. - Global and Planetary Change 71: 141-149.

[11] European Parliament (2016): Report of on cohesion policy in mountainous regions of the European Union, Committee on Regional Development, Available at http://www.europarl.europa.eu/sides/getDoc.do?pubRef=//EP//NONSGML+REPORT+A8-2016-0074+0+DOC+PDF+V0//EN

[12] Garamvölgyi Á., Hufnagel, L. (2013): Impacts of climate change on vegetation distribution No. 1: Climate change induced vegetation shifts in the palearctic region Applied Ecology and Environmental Research 11(1):79-122.

[13] Gee, G. W., Or, D. (2002): Particle-Size Analysis. - In: Dane J.H. and Topp C. (Eds) Methods of Soil Analysis, part 4. SSSA. Madison, WI.

[14] Georghiou, K., Delipetrou, P. (2010): Patterns and traits of the endemic plants of Greece. - Botanical Journal of the Linnean Society 162:130-422.

[15] Hadjigeorgiou, I. (2011): Past, present and future of pastoralism in Greece. - Pastoralism 1(1): $1-22$.

[16] Hadjigeorgiou, I., Osoro, K., Fragoso de Almeida, J.P., Molle, G. (2005): Southern European grazing lands: Production, environmental and landscape management aspects. Livestock Production Science 96: 51 - 59.

[17] Holechek, J. L. (1988): An approach of setting the stocking rate. - Rangelands 10(1): 10 14. 
[18] Holechek, J. L., Pieper, R. D., Herbel, C. H. (2010): Range Management Principles and Practices. Sixth Edition. Prentice-Hall Inc. Upper Saddle River, NJ.

[19] Hunt, 1.P., McIvor, J. G., Grice, A. C., Bray, S. G. (2014): Principles and guidelines for managing cattle grazing in the grazing lands of northern Australia: stocking rates, pasture resting, prescribed fire, paddock size and water points - a review. - The Rangeland Journal 36: 105-119.

[20] Guzman, J.G., Al-Kaisi, M.M. (2011): Landscape position effect on selected soil physical properties of reconstructed prairies in southcentral Iowa. - Journal of Soil and Water Conservation 66(3): 183-191.

[21] Kairis O., Karavitis, C., Salvati, L., Kounalaki, A., Kosmas, K. (2015): Exploring the Impact of Overgrazing on Soil Erosion and Land Degradation in a Dry Mediterranean Agro-Forest Landscape (Crete, Greece). - Arid Land Research and Management 26: 360374.

[22] Karatassiou, M. (2016): Water use efficiency and net production of two semi arid grasslands in different successional stages. - Applied Ecology and Environmental Research 14(2):41-53.

[23] Kirschbaum, M.U.F. (2006): The temperature dependence of organic-matter decomposition-still a topic of debate. - Soil Biology and Biochemistry 38: 2510-2518.

[24] Kirschbaum, M.U.F. (1995): The temperature dependence of soil organic matter decomposition, and the effect of global warming on soil organic $\mathrm{C}$ storage. - Soil Biology and Biochemistry 27(6): 753-760.

[25] Kuo, S. (1996). Phosphorous. - In: Sparks D.L. (Ed). Methods of soil analysis, part 3. Soil Science Society of America. Madison. Wisconsin.

[26] Lwiwski, T.C., Koper, N., Henderson, D.C. (2015): Stocking Rates and Vegetation Structure, Heterogeneity, and Community in a Northern Mixed-Grass Prairie. Rangeland Ecology \& Management 68(4): 322-331.

[27] McMorran, R., Santini, F., Guri, F., Gomez-y-Paloma, S., Price, M., Beucherie, O., Monticelli, C., Rouby, A., Vitrolles et Guillaume Cloye, D. (2015): A mountain food label for Europe? The role of food labelling and certification in delivering sustainable development in European mountain regions. - Journal of Alpine Research 103-4.

[28] Manyeverea, A., Muchaonyerwab, P., Mnkenia, P.N.S., Lakera, M.C. (2016): Examination of soil and slope factors as erosion controlling variables under varying climatic conditions. - CATENA 147: 245-257.

[29] Minson, D.J. (1990): Forage in Ruminant Nutrition. - Academic Press, Sydney.

[30] Mountousis I., Papanikolaou, K., Stanogias, G., Chatzitheodoridis, G., Roukos, C. (2008): Seasonal variation of chemical composition and dry matter digestibility of rangelands in NW Greece. - Journal of Central European Agriculture 9(3): 547-556.

[31] Mountousis, I., Dotas, V., Stanogias, G., Papanikolaou, K., Roukos, C., Liamadis, D. (2011): Altitudinal and seasonal variation in herbage composition and energy and protein content of grasslands on Mt Varnoudas, NW Greece. - Animal Feed Science and Technology 164(3): 174-183.

[32] Mpokos, P., Yiakoulaki, M., Papazafeiriou, A., Sgardelis, S., Alifragis, D., Papanikolaou, K. (2014). Herbage production and species richness in sub-alpine grasslands of different soil parent material in Northern Greece. - Journal of Mountain Science 11(6): 1579-1592.

[33] National Research Council (1985): Nutrients Requirements of Sheep, 6th revised ed. National Academy Press, Washington, DC, USA.

[34] Nelson, D.W., Sommers, L.E. (1996): Total Carbon, Organic Carbon, and Organic Matter, In Sparks D.L. (ed.) Methods of soil analysis, Part 3, Soil Science Society of America. Madison. Wisconsin.

[35] Noziere, P., Graulet, B., Lucas A., Martin B., Grolier P., Doreau M. (2006): Carotenoids for ruminants: From forages to dairy products. - Animal Feed Science and Technology 131: 418-450. 
[36] Oyonarte C., Aranda, V., Durante, P. (2008): Soil surface properties in Mediterranean mountain ecosystems: Effects of environmental factors and implications of management. - Forest Ecology and Management 254:156-165.

[37] Oztas, T., Koc, A., Comakli, B. (2003): Changes in vegetation and soil properties along a slope on overgrazed and eroded rangelands. - Journal of Arid Environments 55:93-100.

[38] Papanastasis, A. (1982): Production of natural grasslands in relation to air temperature and precipitation in northern Greece. Forest Research Institute. Thessaloniki, Greece.

[39] Papanastasis V. P., Koukoulakis, P. H. (1988): Effects of fertilizer application to grasslands in Greece. - Grass and Forage Science 43: 151-158.

[40] Papanastasis V., Kyriakakis, S., Kazakis, K. (2002): Plant diversity in relation to overgrazing and burning in mountain mediterranean ecosystems. - Journal of Mediterranean Ecology 3(2-3): 53-63.

[41] Papanastasis, V., Vrachnakis M., Chourvadas D., Iovi K., Berdeli M., Ispikoudis, I. (2003): Role of altitude and soil depth in the productive potential of natural grasslands of Macedonia, northern Greece. - Grasslands Science in Europe 8:21-24.

[42] Papanastasis, V.P. (1981): The Rangelands of Greece. - Rangelands 3(6): 241-242.

[43] Papanikolaou, K., Roukos, C., Pappa-Michailidou, V., Nikolakakis, I. (2005): Plant biodiversity in the Greek subalpine-alpine rangelands. In: Georgoudis, A., Rosati, A., Mosconi, C. (Eds), Animal Production and Natural Resources Utilisation in the Mediterranean Mountain Areas. EAAP Scientific Series No. 115, Wageningen Academic Publishers.

[44] Paré, D., Boutin, R., Larocque, G.R., Raulier, F. (2006): Effect of temperature on soil organic matter decomposition in three forest biomes of eastern Canada. - Canadian Journal of Soil Science 86: 247-256.

[45] Pérez Corona, M.E., Vazquet de Aldana, B.R., Garcia-Criado, B., Garcia-Ciudad, A. (1998) : Variations in nutritional quality and biomass production of semiarid grasslands. Journal of Range Management 51:570-576.

[46] Prasad, R., Power, J.F. (1997): Soil fertility management for sustainable agriculture. Lewis Publishers. New York, USA.

[47] Rezaei, S.A., Gilkes, R.J. (2005): The effects of landscape attributes and plant community on soil chemical properties in rangelands. - Geoderma 125: 167-176.

[48] Roukos, C., Papanikolaou, K., Karalazos, A., Chatzipanagiotou, A., Mountousis, I., Mygdalia, A. (2011a): Changes in nutritional quality of herbage botanical components on a mountain side grassland in North-West Greece. - Animal Feed Science and Technology 169: 24-34.

[49] Roukos, C., Papanikolaou, K., Mountousis, I., Kandrelis, S., Chatzitheodoridis, F. (2011b): Soil properties variations in relation to plant community and altitudinal zone in the rangelands of Epirus, Greece. - Bulgarian Journal of Agricultural Science: 17(6): 806 -815 .

[50] Roukos, C., Papanikolaou, K., Kandrelis, S., Koutsoukis, C., Chatzitheodoridis, F. (2010): Rain use efficiency factor and grazing capacity in Preveza Prefecture rangelands, Greece. - World Applied Sciences Journal 8(8): 917-922.

[51] Shakhane, L.M., Scott, J.M., Murison, R., Mulcahy, C., Hinch, G.N., Morrow, A., Mackay, D.F. (2013): Changes in botanical composition on three farmlets subjected to different pasture and grazing management strategies. - Animal Production Science 53: 670-684.

[52] Sheatch, G.W., Carlson. W.T. (1998): Impact of cattle treading on hill land. 1. Soil damage patterns and pasture status. - New Zealand Journal of Agricultural Research 41: 271-278.

[53] Thomas, G.W., 1996. Soil pH and soil acidity. - In D.L. Sparks (ed.) Methods of soil analysis, Part 3. Soil Science Society of America. Madison. Wisconsin.

[54] Vazquez-de-Aldana B.R., García-Ciudad, A., Pérez-Corona, M.E., García-Criado, B. (2000): Nutritional quality of semi-arid grassland in western Spain over a 10-year period: 
changes in chemical composition of grasses, legumes and forbs. - Grass and Forage Science 55: 209-220.

[55] Yimer, F., Ledin, S., Abdelkadir, A. (2006): Soil property variations in relation to topographic aspect and vegetation community in the south-eastern highlands of Ethiopia. - Forest Ecology and Management 232: 90-99.

[56] Zervas, G. (1998): Quantifying and optimizing grazing regimes in Greek mountain systems. - Journal of Applied Ecology 35: 983-986.

[57] Zioganas, C., Kitsopanidis, G., Papanagiotou, E., Kanteres, N. (2001): Comparative technical - economical analysis of sheep and goat production according the geographical region of Greece. Dept of Agricultural Economics Research and ETIAGE, Thessaloniki. Greece.

[58] Zhang, J., Dong, Y. (2009): Effects of grazing intensity, soil variables, and topography on vegetation diversity in the subalpine meadows of the Zhongtiao Mountains, China. - The Rangeland Journal 31: 353-360. 